
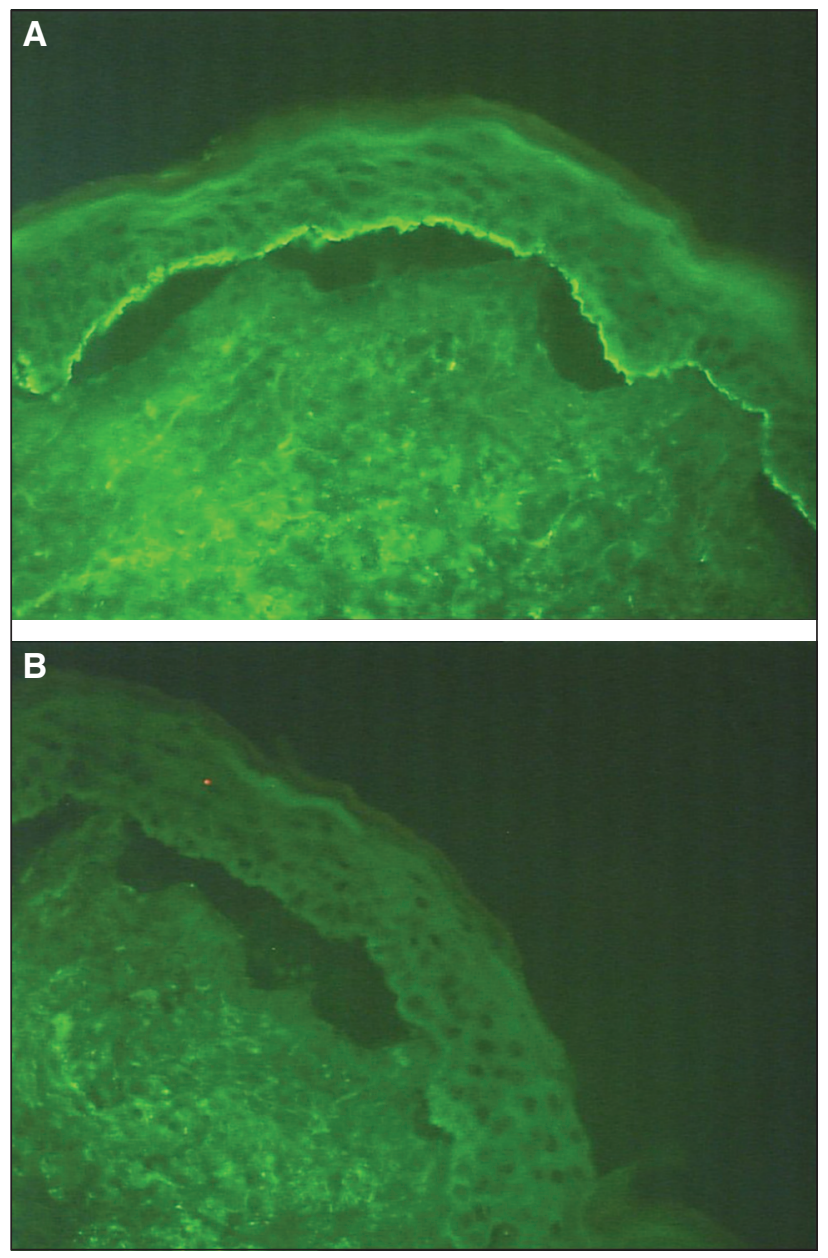

Figure 1. IIF using $1 \mathrm{~mol} / \mathrm{L} \mathrm{NaCl}$ split normal human skin as a substrate.

autoantigen of LABD by immunoblot studies in only a few reports $[4,5]$.

The major target antigen in LABD is LAD-1, a protein of $120 \mathrm{k}-\mathrm{Da}$, which is a proteolytic fragment of the extracellular domain of BP180 as a result of its cleavage on the surface of keratinocytes by the action of an enzyme. This enzyme belongs to the family of ADAMTS (A disintegrin and A metalloprotease). The other well known antigen is a $97 \mathrm{k}-$ Da protein which is a fragment of the $120 \mathrm{k}$-Da protein [6]. In our immunoblot analysis, we also found autoantibodies reactive with a $97 \mathrm{k}$-Da protein, but less reactive.

In this case, we report the novel finding of an $\operatorname{IgA}$ directed against a protein of $200 \mathrm{k}$-Da located on the epidermis. Zone et al. also found a band at $200 \mathrm{k}-\mathrm{Da}$ in patient's serum with LABD [4]. In fact, this $200 \mathrm{k}$-Da band, reactive with whole serum, was not present when the purified antibody was used. This suggested that the antibody that bound to this $200 \mathrm{k}-$ Da band was not purified by the immunoaffinity process using human BMZ. These results suggested that the presence of those antibodies may be just an epiphenomenon. However, Fujimoto et al. [6] showed that circulating IgA autoantibodies to 200 and $280 \mathrm{k}$-Da antigens were detected in an LABD patient's serum by immunoblot analysis using extracts from normal human epidermis and human epidermal keratinocytes. These two antibodies also reacted with the epidermal side of $1 \mathrm{~mol} / \mathrm{L} \mathrm{NaCl}$ split skin on IIF

microscopy and bound to hemidesmosomes as determined by immunoperoxydase electronic microcopy. Our results may also suggest the presence of $200 \mathrm{k}-\mathrm{Da}$ hemidesmosomal proteins as target antigens in linear IgA disease. Our observation supports the contention that LAD is a heterogeneous disease. Further studies need to investigate if these antibodies directed toward a protein of $200 \mathrm{k}$-Da are pathogenic, where this $200 \mathrm{k}$-Da protein is situated and which protein of the BMZ is implicated in such cases.

Disclosure. Financial support: none. Conflict of interest: none.

${ }^{1}$ Department of Dermatology,

University Hospital of Brest,

2 avenue Foch,

29200 Brest,

France

2 Department of Pathology,

University Hospital of Brest,

2 avenue Foch,

29200 Brest,

France

${ }^{3}$ Department of Immunopathology,

University Hospital of Rouen,

France

$<$ karentalour@hotmail.com>

1. Paul C, Wolkenstein P, Prost C, et al. Drug-induced linear $\lg \mathrm{A}$ disease: target antigens are heterogeneous. $\mathrm{Br} J$ Dermatol 1997; 136: 406-11.

2. Christophoridis S, Büdinger L, Borradori L, Hunziker T, Merk HF, Hertl M. $\lg G, \lg A$ and $\lg E$ autoantibodies against the ectodomain of BP 180 in patients with bullous and cicatricial pemphigoid and linear IgA bullous dermatosis. Br J Dermatol 2000; 143: 349-55.

3. Jonkman MF, Groot $A C$, Slegers TP, Jong MC, Pas HH. Immune diagnosis of pure ocular mucous membrane pemphigoid: indirect immunofluorescence versus immunoblot. Eur J Dermatol 2009 ; 45660

4. Zone JJ, Taylor TB, Kadunce DP, et al. IgA antibodies in chronic bullous disease of childhood react with $97 \mathrm{kDa}$ basement membrane zone protein. J Invest Dermatol 1996; 106: 1277-80.

5. Zhou S, Ferguson DJ, Allen J, Wojnarowska F. The localization of target antigens and autoantibodies in linear $\lg A$ disease is variable: correlation of immunogold electron microscopy and immunoblotting. Br J Dermatol 1998; 139:591-7.

6. Fujimoto $W$, Ohtsu T, Toi Y, Nakanishi G, Arata J. Linear IgA disease with $\lg \mathrm{A}$ antibodies directed against 200- and 280-kDa epidermal antigens. Br J Dermatol 2000; 142: 1213-8.

doi:10.1684/ejd.2011.1283

\section{Sjögren-Larsson syndrome due to a novel mutation in the FALDH gene}

Sjögren-Larsson syndrome (SLS) is a rare autosomal recessive disorder characterized by the presence of congenital ichthyosis, spastic diplegia or tetraplegia and mild to moderate mental retardation. SLS is caused by mutations in the ALDH3A2 gene, which encodes for fatty aldehyde dehydrogenase (FALDH) [1-3], an enzyme that catalyzes the oxidation of medium- and long-chain aliphatic aldehydes 
[3-5]. The genotype of SLS patients varies considerably, with many private mutations in individual patients $[4,5]$. We report a 2.5-year-old girl presenting with a history of generalized extremely dry and scaly skin since birth. Her mental and motor development was also delayed; she had spastic diplegia of the legs and expressed herself only in monosyllables. She had been born at gestational week 35, after a normal pregnancy with no antenatal or perinatal complications. There was no history suggestive of a colloidion membrane at the time of birth. Family history showed consanguinity, the parents were second degree cousins, but there were no other relatives with SLS. Gradually the skin lesions worsened, becoming thicker, especially over the flexures, with some lichenified hyperkeratosis (figure 1). The lesions were very pruritic. Scaling and hyperlinearity of palms and soles was present. Ophthalmological and otorhinolaryngological examination was normal.

Magnetic resonance imaging of the brain revealed unmyelinated white matter, and the proton spectroscopy demonstrated an abnormal white matter peak at $1.3 \mathrm{ppm}$. Histopathologic examination showed orthohyperkeratosis, acanthosis and papillomatosis. Genetic analysis of the patient detected a delection of thymidine at position 805 of the exon 6 [c.805delT (p.Tyr269fsX5)] of the FALDH gene in a homozygous state. The same mutation was found in heterozygous state in both parents. This mutation has not been previously reported and functional analysis was not performed. However, as it introduces a premature stop condon, it is predicted to cause either a reduced expression of the mRNA or a truncated protein, with consequent reduction of the amount of enzyme produced or loss of enzymatic function, respectively.

SLS is a chronic disabling neurocutaneous disease with autosomal recessive inheritance that was described in detail

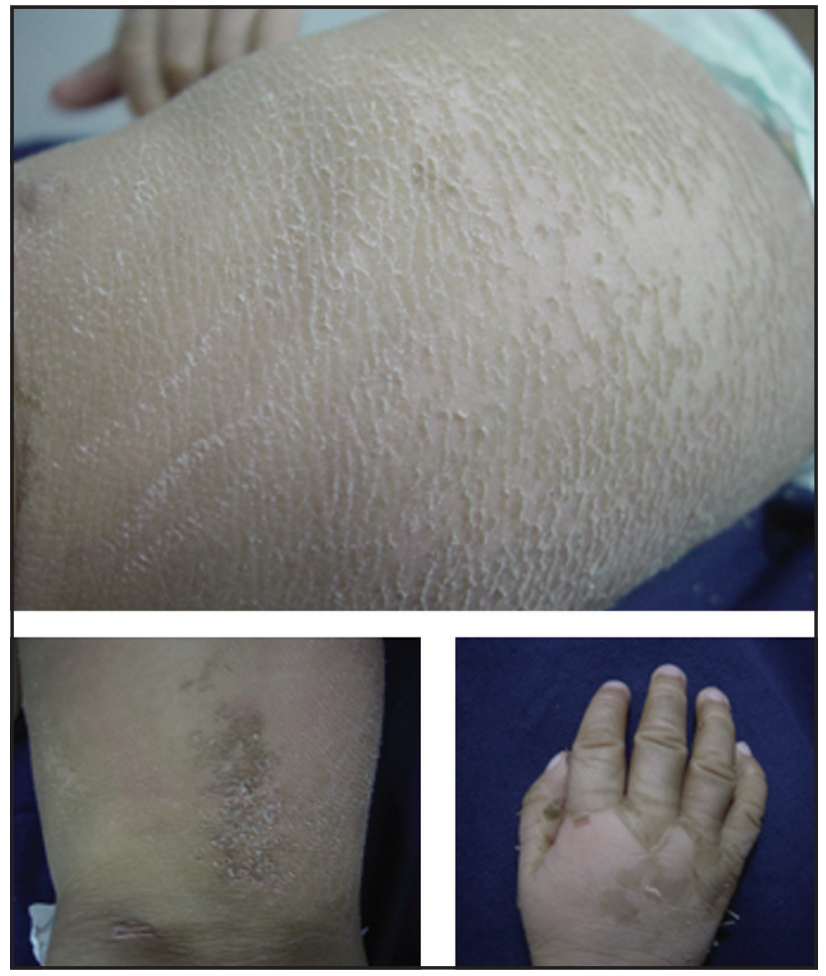

Figure 1. Generalized dry and scaly skin. by two Swedish psychiatrists, Sjögren and Larsson, in 1957 [1]. It is caused by mutations in the ALDH3A2 gene, however the relationship between the genotype and the clinical phenotype of SLS has been difficult to establish [4]. The consequent accumulation of fatty aldehyde precursors, including fatty alcohols, caused by the FALDH deficiency, is postulated to affect the normal formation of multilamellar membranes in the stratum corneum and myelin, and to result in the symptoms [5].

The neurological features of SLS appear in the first years of life and then seem to stabilize [5]. Cerebral proton magnetic resonance spectroscopy in patients with SLS demonstrates an abnormal white matter peak at $1.3 \mathrm{ppm}$ [6], consistent with long-chain fatty alcohol accumulation and coincides with retarded myelination [5].

The diagnosis of SLS is invariably delayed, similarly to other rare genodermatosis. On clinical grounds the diagnosis should be suspected in infants with congenital ichthyosis, especially with emerging neurological features. The ichthyosis is usually the first signal that brings the patient to medical attention, emphasizing the role of the dermatologist in the diagnosis. Unlike most other forms of ichthyosis, it has a disturbing pruritic character and, as in our case, patients tend to be born preterm.

To our knowledge, the mutation of our patient has not been previously reported, supporting the rich mutational heterogeneity associated with this syndrome.

Disclosure. Financial support: none. Conflict of interest: none.

\begin{tabular}{l|r}
${ }^{1}$ Dermatology Department Hospital & Joana Maria BOTELHO \\
de Braga, & GOMES $^{\mathbf{1}}$ \\
Apartado 2242, & Ana Paula VIEIRA ${ }^{\mathbf{1}}$ \\
$4701-965$ Braga, & Jorge NAVARRO ${ }^{\mathbf{2}}$ \\
Portugal & Ricardo MARE $^{\mathbf{3}}$ \\
${ }^{2}$ Casa de Sáude de Guimarães, & Purificação TAVARES \\
Guimarães, & Celeste BRITO $^{\mathbf{1}}$
\end{tabular}

Portugal

${ }^{3}$ Neurology Department,

Hospital de Braga,

Portugal

${ }^{4}$ CGC genetics,

Porto,

Portugal

<gbmjoana@yahoo.com>

1. De Laurenzi V, Rogers GR, Hamrock DJ, et al. Sjögren-Larsson Syndrome is caused by mutations in the fatty aldehyde dehydrogenase gene. Nat Genet 1996; 12:52-7.

2. Rizzo WB. Sjögren-Larsson syndrome. Semin Dermatol 1993; 12 : 210-8.

3. Auada MP, et al. Sjögren-Larsson syndrome: biochemical defects and follow up in three cases. Eur J Dermatol 2002; 12: 263-6.

4. Auada MP, Puzzi MB, Cintra ML, et al. Sjögren-Larsson Syndrome in Brazil is caused by a common c. 1 108-1G $\rightarrow$ C splice-site mutation in the ALDH3A2 gene. Br J Dermatol 2006; 154: 770-3.

5. Lassos A, Khoury $M$, Rizzo W, et al. Phenotypic variability among adult siblings with Siögren-Larsson Syndrome. Arch Neurol 2006; 63: 278-80.

6. Mano T, Ono J, Kaminaga $T$, et al. Proton MR Spectroscopy of Siögren-Larsson Syndrome. Am J Neuroradiol 1999; 20: 1671-3.

doi:10.1684/ejd.2011.1286 